Євсєєв І.Г., науковий співробітник науководослідного відділу науково-дослідного иентру воєнної історії НУО Украӥни імені Івана Черняховського (м. Київ)

\title{
ОПЕРАЦІЯ ОБ'ЄДНАНИХ СИЛ У ДОНЕЦЬКІЙ ТА ЛУГАНСЬКІЙ ОБЛАСТЯХ: ПЕРЕДУМОВИ ЗАПРОВАДЖЕННЯ
}

У статті наведено основні підсумки проведення антитерористичної операчіï; обтрунтовано необхідність змінення формату ї проведення; здійснено аналіз нормативно-правових актів щодо запровадження операчії Об'єднаних сил у Донещькій та Луганській областях.

Ключові слова: антитерористична операція, операція Об'єднаних сил, нормативно-правовий акт, деокупація.

Необхідність протидії гібридній війні Російської Федерації (далі - РФ) проти України вимагає принципово нових підходів i стратегій до забезпечення національної безпеки і оборони України, вибору ефективних механізмів захисту національних інтересів від нинішніх та потенційних загроз воєнного характеру. Враховуючи це, у 2018 році було розпочато новий формат відбиття збройної агресії РФ та запроваджено операцію Об'єднаних сил із забезпечення національної безпеки і оборони, відсічі та стримування збройної агресії Російської Федерації у Донецькій та Луганській областях (далі - ООС), що потребує проведення окремого воєнно-історичного дослідження.

У статті на основі використання низки законодавчих актів Верховної Ради України, указів Президента України, наказів Верховного Головнокомандувача Збройних Сил України, а також наукових праць із зазначеної проблематики, зокрема матеріалів Аналітичної доповіді до Щорічного Послання Президента України до Верховної Ради України “Про 
внутрішне та зовнішне становище України в 2018 році”, висвітлено передумови запровадження операції Об'єднаних сил у 2018 році.

Відповідно до міжнародного та національного законодавства Україна як держава зобов'язана відповідати за приналежну їй територію, припиняти будь-які спроби силових дій, що загрожують тї територіальній цілісності, життю i здоров’ю iї громадян. Захоплення незаконними збройними формуваннями окремих територій Сходу України у березні-квітні 2014 року могло бути зупинено тільки адекватними діями. Військово-політична ситуація, що виникла на Сході України, зумовила необхідність прийняття рішення про збройний опір російській агресії та її ставленикам [1, с. 14].

Так, у відповідь на приховану збройну агресію Російської Федерації проти України та дії незаконних збройних формувань на Донбасі, що мали ознаки терористичної діяльності, Указом Президента України від 14 квітня 2014 року № 405/2014 було введено в дію рішення Ради національної безпеки і оборони України (далі - РНБОУ) "Про невідкладні заходи щодо подолання терористичної загрози і збереження територіальної цілісності України". Згідно $з$ цим рішенням в окремих районах Донецької та Луганської областей було розпочато широкомасштабну антитерористичну операцію (далі - ATO) iз залученням Збройних Сил (далі - ЗС) України, Національної гвардії України та Служби безпеки України (далі - СБУ) [2; 3].

АТО відбувалась на підставі Закону України "Про боротьбу 3 тероризмом” і полягала у вжитті скоординованих спеціальних заходів, спрямованих на попередження, запобігання, припинення терористичної діяльності та мінімізацію іiі наслідків, звільнення заручників, забезпечення безпеки населення, знешкодження терористів. Керівництво цією операцією згідно чинного законодавства України було покладено на СБУ, що $є$ головним органом у загальнодержавній системі боротьби з терористичною діяльністю [3]. 
Юридично Україна проводила АТО, здійснюючи своє невід’ємне право на самооборону відповідно до статті 51 Статуту ООН і статті 1 Закону України “Про оборону України" [4, с. 8].

За час проведення АТО вдалося зупинити розширення російської агресії на всю територію суверенної України та здійснити локалізацію зони збройного протистояння; вжити заходів із підвищення бойових спроможностей 3С, інших військових формувань, розвідувальних та правоохоронних органів (далі - сили оборони); посилити обороноздатність держави; забезпечити підготовку ії території, економіки та населення до оборони тощо. У 2014 році під контроль української влади було повернуто понад 200 населених пунктів Донецької та Луганської областей, сформовано 29 нових бойових бригад і полків, створено окремі роди військ: Десантноштурмові війська та Сили спеціальних операцій, реформовано систему територіальної оборони, створено оперативний резерв, до якого зараховано більше 198 тис. резервістів, які мають досвід виконання завдань у зоні бойових дій [5; 6, с. 158].

Проведена у 2014-2015 роках у рамках комплексного огляду сектору безпеки і оборони оцінка стану воєнної безпеки держави, а також набутий досвід участі ЗС України, інших військових формувань, розвідувальних та правоохоронних органів у АТО стали підгрунтям для розроблення в державі основоположних документів оборонного планування: Стратегії національної безпеки України, Воєнної доктрини України, Концепції розвитку сектору безпеки і оборони України, Стратегічного оборонного бюлетеня України, Державної програми розвитку Збройних Сил України на період до 2020 року, а також інших концептуальних (доктринальних) документів реформування i розвитку складових сил оборони та державних програм розвитку обороннопромислового комплексу, озброєння і військової техніки.

Прийняття цих важливих державних документів надало потужний поштовх для запровадження в Україні у 2016 році оборонної реформи, дало змогу забезпечити ефективну координацію дій та покращити систему 
управління складовими сектору безпеки i оборони, удосконалити організаційно-правову, матеріально-технічну, медичну, логістичну та інші системи забезпечення. Поряд із цим українські військовослужбовці, співробітники спеціальних служб та правоохоронних органів набули практичного бойового досвіду у сферах своїй діяльності. Цей досвід має бути переданий наступним поколінням захисників нашої держави.

ATO продемонструвала наявність в Україні громадянського суспільства та його позитивну роль у сфері забезпечення національної безпеки і оборони держави. Суспільство показало вражаючу здатність до консолідації і мобілізації, зумівши створити дієву мережу громадських ініціатив та об'єднань, які взяли на себе вирішення найбільш гострих та невідкладних завдань. Волонтерський рух дав державі змогу налагодити ефективне функціонування складових сектору безпеки і оборони. Волонтери відіграли ключову роль як у проведенні АТО, так і у вирішенні гуманітарних питань у зоні збройного конфлікту та довели, що без підтримки з боку громадян суб'єктам боротьби з тероризмом неможливо було б виконувати поставлені завдання.

Стало очевидним, що такі сфери діяльності держави, як національна безпека і оборона стають предметом опікування громадянського суспільства, яке на початку АТО активно перебирало на себе відповідну низку завдань та функцій держави із забезпечення їі проведення [6, с. 159]. Крім того, до АТО долучилися добровольчі формування, відомі як “добровольчі батальйони”. Поява в українському суспільстві такого феномену як добровольчий рух, пов'язана з Революцією Гідності та зумовлена агресією РФ проти України.

Військові дії між силами АТО та збройними формуваннями РФ і іiі найманцями протягом чотирьох років відбувались із застосуванням важкого озброєння та військової техніки на території, площа якої становить близько 40 тис. км², а довжина лінії розмежування - 403 км. Такі умови проведення не $є$ притаманними для АТО, що має локальний характер. Крім того, через масштабність збройної боротьби, застосування збройними формуваннями РФ 
i iï найманцями важкого озброєння і військової техніки головна роль у цій операції де-факто вже перейшла до ЗС України, хоча де-юре керівництво АТО покладалося на Службу безпеки України. Отже, подальше звільнення окупованих територій окремих районів Донецької та Луганської областей і відновлення на них конституційного ладу у форматі АТО виявилось неможливим, виникла необхідність створення ефективної системи захисту нашої держави [7, с. 67; 8; 9; 10; 11, с. 14].

Водночас активізація проти нашої держави диверсійно-підривної, інформаційно-психологічної діяльності та підвищення рівня злочинності суттєво впливають на соціальний добробут населення окупованих територій. Норми, що розроблялися для захисту інтересів людини, суспільства і держави в умовах мирного часу, не дають останній можливості повноцінно захистити права, свободи, інтереси й цінності зазначених суб'єктів. У зв'язку 3 тим, що в Україні не було введено правового режиму воєнного чи надзвичайного стану, а АТО вже давно вийшла за межі свого призначення і набула чітко вираженого військово-оборонного характеру виникла потреба у виробленні нових засад функціонування людини, суспільства i держави $[12$, c. $20 ; 13$, c. 85$]$.

У таких умовах постало завдання створити правові механізми ефективного використання сектору безпеки і оборони для захисту держави від збройної агресії РФ в умовах гібридної війни, розв'язаної проти України. Розроблення таких механізмів, їх своєчасна адаптація до сучасних викликів стали одними 3 головних напрямів правотворчого процесу держави [14, c. 253].

Поряд із цим нагальною проблемою стала також відсутність чіткої законодавчо оформленої правової позиції України щодо тимчасово окупованих РФ українських територій. Україна виходить 3 того, що й загарбаний Крим і окремі райони Донеччини та Луганщини $є$ тимчасово окупованими територіями, право на які Українська держава не втратила, і які підлягають поверненню. 3 точки зору міжнародного права режим цих 
територій однаковий, вони юридично залишаються частинами території України і мають бути повністю звільненими окупантами [4, с. 8].

3 метою правового врегулювання вищезазначених проблемних питань Верховна Рада України прийняла Закон України "Про особливості державної політики iз забезпечення державного суверенітету України на тимчасово окупованих територіях у Донецькій та Луганській областях" (далі - “Закон про деокупацію Донбасу”).

“Закон про деокупацію Донбасу” створив умови для встановлення нового організаційно-правового режиму протидії російській агресії - “заходи iз забезпечення національної безпеки i оборони, стримування i відсічі російської збройної агресії в Донецькій та Луганській областях", надав можливість змінити попередній формат АТО та порядок застосування ЗС України, інших військових формувань та правоохоронних органів держави [15].

Варто відмітити, що зазначений законодавчий акт не містить чіткого сценарію повернення тимчасово окупованих територій, проте він закріплює порядок протидії збройній агресії РФ на території Донецької та Луганської областей, дає роз'яснення щодо правових підстав застосування усіх можливих засобів і ресурсів та має низку переваг.

По-перше, згідно 3 прийнятим законодавчим документом РФ визнається країною-агресором, що розв’язала проти України міждержавний збройний конфлікт, окупувала частину іiі території та постійно підживлює загострення бойових дій на окупованій частині Донбасу. Цей нормотворчий акт не уточнює окремої дати початку агресії на Донбасі, проте він містить посилання на законодавство України [16], де вказано дату початку окупації частини території України - 20 лютого 2014 року. Таке твердження є важливим моментом, оскільки законодавчо закріплює факт, що РФ почала агресію проти Україну з Криму, а не з Донбасу. Отже, саме Росія несе відповідальність за порушення захисту прав цивільного населення на окупованій нею території України. 
По-друге, ухвалені в законі рішення створюють належні правові підстави для підготовки консолідованої претензії до РФ про відшкодування завданих збитків унаслідок вчинення нею агресії, уможливлює реалізацію законного права України на самооборону, а також створює передумови для оцінки подій в Україні як збройного конфлікту міжнародного характеру, а не як внутрішнього збройного конфлікту (громадянської війни), на чому так наполягає Росія [6, с. 160].

По-третє, важливим є визначення окупованою РФ не тільки української сухопутної території, а й морських вод та повітряного простору, що надає статус, в межах якого діє міжнародне гуманітарне право, слугує правовим механізмом для залучення гуманітарної допомоги, моніторингових місій та миротворчих сил [14, с. 255].

По-четверте, Верховна Рада України схвалила рішення Президента України про використання 3С України та інших утворених відповідно до законів України військових формувань, що призначаються для відсічі і стримування збройної агресії РФ, забезпечення державного суверенітету України на тимчасово окупованих територіях у Донецькій та Луганській областях [15].

Цим було створено законодавчі умови для формування на Донбасі міжвідомчого угруповання об’єднаних сил і засобів Збройних Сил України, інших військових формувань, Міністерства внутрішніх справ України, Національної поліції України, центрального органу виконавчої влади, що реалізує державну політику у сфері цивільного захисту (далі - міжвідомче угруповання). Крім цього, було запроваджено відповідну систему керівництва та управління міжвідомчим угрупованням для здійснення планування, організації та контролю за виконанням заходів із забезпечення національної безпеки і оборони, відсічі і стримування збройної агресії у Донецькій та Луганській областях.

Головними політичними та військовими суб'єктами створеної системи є Президент України - Верховний Головнокомандувач Збройних Сил 
України, начальник Генерального штабу - Головнокомандувач Збройних Сил України, якому підпорядковується Командувач Об'єднаних сил (далі Командувач OC). Командувач ОС здійснює керівництво силами та засобами 3С України, інших утворених відповідно до законів України військових формувань, Міністерства внутрішніх справ України, Національної поліції України, центрального органу виконавчої влади, що реалізовує державну політику у сфері цивільного захисту, які залучаються до здійснення заходів із забезпечення національної безпеки і оборони, відсічі і стримування збройної агресії РФ безпосередньо у Донецькій та Луганській областях. Він реалізовує свої повноваження через підпорядкований йому Об'єднаний оперативний штаб Збройних Сил України (далі - ООШ ЗС України) [11, с. 15].

По-п’яте, відповідно до “Закону про деокупацію Донбасу” начальника Генерального штабу - Головнокомандувача Збройних Сил України наділено правом визначати межі зон безпеки, прилеглих до району бойових дій. Для здійснення заходів із забезпечення національної безпеки і оборони, відсічі і стримування російської збройної агресії на Донбасі у цих зонах діє особливий порядок, що передбачає надання органам сектору безпеки i оборони, іншим державним органам України спеціальних розширених повноважень, необхідних для здійснення заходів із забезпечення національної безпеки і оборони, відсічі і стримування агресії.

У зв’язку із необхідністю подальшої реалізації “Закону про деокупацію Донбасу" Президент України - Верховний Головнокомандувач Збройних Сил України призначив генерал-лейтенанта С. Наєва Командувачем Об’єднаних сил, а 30 квітня 2018 року ввів у дію рішення РНБОУ “Про широкомасштабну антитерористичну операцію в Донецькій та Луганській областях" щодо зміни формату широкомасштабної АТО, розпочатої 14 квітня 2014 року [17; 18].

Водночас Президент України - Верховний Головнокомандувач Збройних Сил України видав накази “Про початок операції Об’єднаних сил із забезпечення національної безпеки й оборони, відсічі та стримування 
збройної агресії Російської Федерації на території Донецької та Луганської областей” та “Про затвердження положення про Об'єднаний оперативний штаб Збройних Сил України”, відповідно до яких у державі з 14.0030 квітня 2018 року було розпочато ООС, а також визначено функції, основні завдання та повноваження Об'єднаного оперативного штабу Збройних Сил України (далі - ООШ) [19]. Проведення ООС передбачено в умовах правового режиму мирного часу з можливістю введення правового режиму воєнного стану у разі розширення збройної агресії РФ [12, с. 8].

Зазначені документи створили необхідні нормативно-правові, організаційні, кадрові та інші підстави для запровадження ООС у Донецькій та Луганській областях. Ця операція стала принципово новою для ЗС України за цілями, складом учасників, формою та організацією керівництва й управління. Головними цілями такої операції $\epsilon$ здійснення заходів із забезпечення національної безпеки й оборони на Донбасі, відсічі і стримування російської збройної агресії, посилення захисту українських громадян у цьому регіоні, а у перспективі і відновлення територіальної цілісності України.

Для досягнення зазначених цілей ООС було вперше сформовано міжвідомче угруповання - Об'єднані сили (далі - ОС) у складі двох оперативно-тактичних угруповань "Північ" та "Схід" із відповідним комплектом військових частин (підрозділів) та резервів. До їх складу увійшли сили й засоби (особовий склад та спеціалісти окремих підрозділів, військових частин, зброя, бойова техніка, спеціальні і транспортні засоби, засоби зв'язку та телекомунікацій, інші матеріально-технічні засоби) ЗС України, інших військових формувань, розвідувальних та правоохоронних органів, а також працівники закладів охорони здоров'я України. Специфічною для ОС стала система координації дій військових та правоохоронних структур, їхня співпраця 3 військово-цивільними адміністраціями, адже пріоритетами спільної роботи є відновлення та розбудова зруйнованої під час бойових дій інфраструктури, зокрема 
соціальних об'єктів, що знаходяться у районах, що безпосередньо межують із лінією зіткнення [20, с. 335].

Головна відмінність ООС від АТО полягає в підпорядкованості. Якщо АТО проводили під загальним керівництвом Антитерористичного центру Служби безпеки України, то ООС - під керівництвом начальника Генерального штабу - Головнокомандувача Збройних Сил України. Йому також надано право, у разі загострення обстановки, залучати до їх складу додаткові сили й засоби ЗС України, усі без винятку силові підрозділи, інші складові частини сектору оборони держави.

Гібридною, військово-безпеково-правоохоронною $є$ i форма проведення ООС. Крім виконання ЗС України та іншими військовими формуваннями завдань з оборони держави на Донбасі (стримування і відсічі російської збройної агресіі), угруповання ОС виконує функцію із забезпечення національної безпеки, у тому числі громадської, інформаційної протидії російській пропаганді, цивільного захисту населення, контролю за в’їздом осіб, переміщенням товарів на тимчасово окуповані території у Донецькій та Луганській областях і виїздом осіб, переміщенням товарів із цих територій через пункти в’їзду-виїзду тощо. У разі необхідності ОС виконуватимуть також завдання з деокупації відповідних районів Донецької та Луганської областей [21, с. 12].

ООШ ЗС України через підлеглі органи військового управління здійснює планування, організацію та контроль за виконанням заходів із забезпечення національної безпеки й оборони, відсічі і стримування російської збройної агресії на Донбасі, координацію й контроль за діяльністю військово-цивільних чи військових адміністрацій (у разі їх утворення) у Донецькій та Луганській областях із питань національної безпеки й оборони. При цьому всі військовослужбовці, працівники правоохоронних органів та інші особи ОС підпорядковуються Командувачу об'єднаних сил, рішення якого є для них обов'язковими до виконання [6, с. 163-164]. 
Отже, у результаті проведення АТО нашій державі вдалося зупинити розширення російської агресії на Сході України та здійснити локалізацію зони збройного конфлікту, що дало змогу набути досвід у протистоянні цій агресії, вжити заходів із підвищення бойових спроможностей сил оборони та розпочати оборонну реформу.

Подальше продовження АТО під керівництвом Служби безпеки України через обмеженість такої операції та масштабність збройної боротьби було неспроможне забезпечити звільнення тимчасово окупованих територій окремих районів Донецької та Луганської областей. На законодавчому рівні перед державою постало завдання не лише визначення правового статусу цих тимчасово окупованих територій, а й формування засад державної політики щодо їх звільнення.

“Закон про деокупацію Донбасу” та акти Верховного Головнокомандувача Збройних Сил України створили нормативно-правове підгрунтя для запровадження операції Об'єднаних сил та вирішення завдань 3 відсічі ворожої агресії на Донбасі, а у перспективі відновлення територіальної цілісності України. Завдяки цьому в 2018 році у Донецькій та Луганській областях України було сформовано необхідне міжвідомче угруповання військ та сил, налагоджено його взаємодію 3 іншими складовими сил оборони, військово-цивільними адміністраціями в Донецькій та Луганській областях.

\section{Список використаних джерел і літератури}

1. Біла книга антитерористичної операції на Сході України (2014-2016) / під заг. ред. І. Руснака. - Київ : Національний університет оборони України імені Івана Черняховського, 2017. - 162 с.

2. Про рішення Ради національної безпеки і оборони України від 13 квітня 2014 року “Про невідкладні заходи щодо подолання терористичної загрози і збереження територіальної цілісності України” : Указ Президента 
України від 14.04.2014 № 405/2014 / Президент України // Офіційний вісник Президента України. - 2014. - № 14. - Ст. 745.

3. Про боротьбу з тероризмом : Закон України від 20.03.2003 № 638-IV / Верховна Рада України // Відомості Верховної Ради України. - 2003. № 25. - Ст. 180.

4. Василенко В. Питання правового врегулювання статусу окупованих територій. Стратегія щодо Донбасу: політичний, економічний та гуманітарний вимір / В. Василенко // Матеріали II Відкритої кафедри 3 актуальних питань зовнішньої політики, безпеки та дипломатії (Київ, 24-25 березня 2017 р.). - Київ : ІСЕД, 2017. - С. 8-10.

5. За час російської агресії сформовано 29 бригад і полків - Генштаб: [Електрон. pесурс]. - Режим доступу: https://www.unn.com.ua/uk/news/ 1781244-za-chas-rosiyskoyi-agresiyi-sformovano-29-brigad-i-polkiv-genshtab

6. Аналітична доповідь до Щорічного Послання Президента України до Верховної Ради України "Про внутрішне та зовнішне становище України в 2018 році”. - К. : НІСД, 2018. - 1316 с.

7. Яровий K. Поняття та ознаки території проведення антитерористичної операції / К. Яровий // Національний юридичний журнал: теорія і практика, 2017. - № 3 (25). - С. 66-69.

8. Сирський О. Просте розведення сторін та введення миротворців нічого не вирішить, а лише заморозить конфлікт: [Електрон. ресурс]. Режим доступу : https://www.ukrinform.ua/rubric-ato/2734498-oleksandr-sirskijgenerallejtenent-komanduvac-oos.html

9. Турчинов О. Подальше звільнення окупованих територій у межах формату АТО - неможливе: [Електрон. ресурс]. - Режим доступу: http://www.rnbo.gov.ua/news/2790.html

10. Навіщо потрібно змінювати формат АТО на операцію об'єднаних сил?: [Електрон. ресурс]. - Режим доступу: http://razumkov.org.ua/ komentari/navishcho-potribno-zminiuvaty-format-ato-na-operatsiiu-obiednanykhsyl 
11. Тютюнник B. Закон про реінтеграцію: перша спроба вирішення правових проблем оборони держави на Донбасі / В. Тютюнник // Виклики і ризики. Безпековий огляд Центру дослідження армії, конверсії та роззброєння, 2018. - № 1 (88). - С. 12-22.

12. Дослідження проблем правового регулювання застосування Збройних Сил України, інших військових формувань, правоохоронних органів у збройних конфліктах, їх залучення до антитерористичних та інших операцій в мирний час, з урахуванням стандартів НАТО і досвіду провідних країн світу / керівник Котляренко О. П. // звіт про НДР шифр: “Конвенція" (робочі матеріали). - Київ : ЦВСД НУОУ, 2018. - 98 с. Інв. № 9315.

13. Ірха Ю.Б. Обмеження конституційних прав і свобод людини i громадянина інтересах національної безпеки України в сучасних умовах / Ю. Б. Ірха // Вісник Конституційного суду України. - 2015. - № 5. - С. 78-87.

14. Трофименко А. Операція Об'єднаних сил в Україні: політикоправові засади проведення / А. Трофименко // Вісник Маріупольського державного університету : збірник наукових праць. - 2018. - Вип. 21. C. $253-259$.

15. Про особливості державної політики із забезпечення державного суверенітету України на тимчасово окупованих територіях у Донецькій та Луганській областях : Закон України від 18.01.2018 № 2268-VIII / Верховна Рада України // Відомості Верховної Ради України. - 2018. - № 10. - Ст. 54.

16. Про внесення змін до деяких законів України щодо визначення дати початку тимчасової окупації : Закон України від 15.09.2015 № 685-VIII / Верховна Рада України // Відомості Верховної Ради України. -2015. - № 46. - Ст. 417.

17. Про призначення С. Наєва Командувачем об’єднаних сил : Указ Президента України від 16.03.2018 № 69/2018 / Президент України // Офіційний вісник Президента України. - 2018. - № 8. - Ст. 128.

18. Про рішення Ради національної безпеки і оборони України від 30 квітня 2018 року "Про широкомасштабну антитерористичну операцію в 
Донецькій та Луганській областях" : Указ Президента України від 30.04.2018 № 116/2018 / Президент України // Офіційний вісник Президента України. 2018. - № 10. - Ст. 174.

19. Генеральний штаб ЗСУ / General Staff of the Armed Forces of Ukraine. 30 квітня 2018 р.: [Електрон. ресурс]. - Режим доступу : https://www.facebook.com/GeneralStaff.ua/ posts/974010469434877/

20. Стеиюк С. П. Організація правової роботи у Збройних Силах України в умовах проведення операції Об'єднаних сил на території Донецької та Луганської областей / С. П. Стецюк // Військова освіта і наука: сьогодення та майбутнє : XIV Міжнар. наук.-практ. конф. (Київ, 22 листопада 2018 р.) : тези доповіді. - Київ, 2018. - С. 334-335.

21. Тютюнник В. Виклик часу: перехід від оборони до забезпечення воєнної безпеки України / В. Тютюнник // Наука і оборона. - 2018. - № 3. C. $10-15$.

Yevsieiev I.H., Researcher of Research Division of Research Centre of Military History of Ivan Chernyakhovskyi National Defense University of Ukraine (Kyiv)

\section{JOINT FORCES OPERATION IN DONETSK AND LUHANSK REGIONS: PREREQUISITES}

The article summarizes the main results of the anti-terrorist operation; the necessity to change the format of its conduct is substantiated; analysis of legal acts concerning the introduction of the Joint Forces Operation in Donetsk and Luhansk regions.

Keywords: anti-terrorist operation, Joint Forces Operation, legal act, deoccupation. 